\title{
THE POSSIBILITIES OF PRODUCTION ENGINEERING IN THE DEVELOPMENT OF SMART SPECIALISATIONS ILLUSTRATED WITH THE EXAMPLE OF THE SILESIAN VOIVODESHIP
}

\author{
Witold BIAtY \\ Silesian University of Technology
}

\begin{abstract}
:
Smart specialisations, a new area of economy/science which constitutes a new, growing economic specialisation based on utilising the unique natural resources of a region, connecting various branches of the industry, applying innovative technological solutions. Each Polish voivodeship has a specific list of smart specialisations aimed at creating new markets for economic activity, modernisation and increasing the region's competitiveness. Using as an example the technical universities in the Silesian Voivodeship, the author considers the possibility of teaching future experts for Smart Specialisation implementation as part of the Production Engineering course. He signalises the potential and omissions.
\end{abstract}

Key words: smart specialisations, Production Engineering, innovation strategy, socio-economic development

\section{INTRODUCTION}

The concept of smart specialisation was developed by the "Wiedza dla wzrostu" ("Knowledge for growth") Expert Group, which, as an advisory body, was created in 2005 by the EU Commissioner for Research, Janez Potočnik. The Group was chaired by Potočnik while the vice-chairman was prof. Dominique Foray, a supporter of the concept of smart specialisation and author of numerous papers on the subject $[2,3,4]$. Specialisation applied in this concept is not a new term when it comes to development policy, especially regional.

Smart specialisation is a concept of introducing innovation policy consisting in effective and synergic use of public support to enhance the innovation capabilities by concentrating on the most promising areas of comparative advantage [12]. Smart specialisation can be defined as "an entrepreneurial process of identifying areas of science and technology from the specialisations useful to the given region" [5].

It is assumed that in order to effectively utilise funds invested into science, research and development, regions should aim to position themselves on the regional market and not split their investments into areas in which they will be in a catching-up position. Such an approach should increase the influence of individual policies of the European Union on regional economies. This shall result in more efficient public fund use while simultaneously stimulating grassroot activity [8].

The process of smart specialisation should take place in a bottom-up manner (hence the term: "entrepreneurial process") - regional organisations (companies, research and scientific entities and others) should indicate directions for investment, research and development - defining the strategy for smart specialisation cannot be imposed. At the same time, the role of the public authorities is to encourage an exchange of views, create conditions for constructive discussion and cooperation.

Work on implementing smart specialisation has been started with the support of the European Committee with creating a "platform for smart specialisation" [12], wherein various organisations exchange experiences in order to define the needs, strengths and weaknesses as well as chances and threats.

Smart specialisations should contribute to the transformation of the country's economy by modernising and structurally transforming it, diversifying products and services, and creating innovative socio-economic solutions which support the transformation toward an economy which utilises resources, including natural ones, efficiently.

\section{CHALLENGES OF SMART SPECIALISATION}

The Europe 2020 strategy envisages supporting the smart specialisation of regions, i.e. innovative development of individual areas of specific countries drawing upon their natural resources, traditional industries, etc., in other words all that which makes up their specific character and uniqueness. At the same time the cohesion policy of the European Union requires that the evaluation of effect of smart specialisation be based upon tangible criteria which make it possible to compare the rate and level of development of the regions, and seek to eliminate differences which are disadvantageous to their inhabitants. These criteria also help to evaluate the current state and civilizational progress of the regions and define the challenges they face.

In the EU document, smart specialisation "is the identification of unique qualities and assets of every region, underlining their competitive advantages and bringing regional partners and resources together around a vision of their future directed at achievements. It involves strengthening the regional innovation systems, maximising the flow of 
knowledge and spreading the benefits of innovation within the entire economy of the region."

Smart specialisation is a concept of the European Committee referring to the implementation of innovation technology of the EU's regions and countries based on the RIS3 strategies. The concept has been expanded upon in the "Guide to Research and Innovation Strategies for Smart Specialisations (RIS3)" [5], and defined as:

National/regional research and innovation strategies for smart specialisation (RIS3), i.e. integrated, locally defined economic transformation programmes which meet five important criteria, namely:

- they make it possible to concentrate the support in terms of policy and investments on key national/ regional priorities, challenges and needs pertaining to knowledge-based development, including measures related to ICT;

- they make use of the strengths and competitive advantages of a given country/region as well as its potential to reach perfection;

- they facilitate technological and practical innovations, stimulate investments in the private sector;

- they lead to full engagement by the stakeholders, encourage innovativeness and experimentation;

- they are based on objective data, are evidence-based and have reliable systems for monitoring and assessment.

\section{CLASSIFICATION OF EUROPE'S REGIONS}

The European Union is diverse in terms of being able to benefit from the newest technologies and innovations. According to the report entitled "Innovation pathways and policy challenges at the regional level: smart specialization," created in 2011 by René Wintjes and Hugo Hollanders [9], researchers from the University of Maastricht, the position of individual regions and their openness to innovative solutions depends on three factors:

1. It is influenced by the regions accessibility to knowledge, i.e. all types of connections (communication routes, but also channels of information or business relation flow) it has with other cities, regions and countries. The accessibility depends on e.g. local infrastructure, distance from markets or population density combined with the presence of the so-called knowledge institutions and $\mathrm{B}+\mathrm{R}$ or innovation activity in the region.

2. The region's ability to take in knowledge, which depends mostly on the presence of persons with a sufficient level of qualifications, is also important. The socalled region's receptivity is closely related to the region being equipped with specialised equipment and the activity of specialised professional networks within it. Also important is the availability of services based on knowledge and the occurrence of outsourcing.

3. Spreading knowledge and technology manifested in the distribution of technically advanced products and machines to both international and domestic export markets. The spread of knowledge also includes the flow of knowledge not related to trade, e.g. know-how in professional relations. Foreign investments and the migration of highly qualified experts from one region to another or between different technology fields also contribute to this factor.

René Wintjes and Hugo Hollanders [9] distinguished seven types of regions in terms of accessibility, receptivity and knowledge spreading of the individual areas of the Eu- ropean Union. They presented (proposed) the following division:

1. Group 1 are metropolitan knowledge-intensive services - KIS - regions. It encompasses 23 regions from the densely populated areas of Western Europe. Many of them are capital regions, e.g.: Brussels, Berlin, Paris, Vienna, Helsinki, Stockholm or London. They are characterised by a high level of urbanisation and the highest level of economic activity of all the regions.

2. The second group consists of knowledge absorbing regions, i.e. 76 regions of France, the British Isles, Benelux countries and northern Spain with economic growth rates slightly above the average.

3 . The third group are public knowledge centres, represented by 16 regions mostly from eastern Germany and metropolitan areas of Eastern Europe. They are characterised by an average level of economic activity and intense economic growth.

4. Group 4 encompasses 44 skilled industrial Eastern EU regions. Their common feature is catching up in terms of economic growth.

5. The fifth group consists of high-tech regions and comprises 17 regions with high $B+R$ activity from Germany, Finland, Sweden and The Netherlands.

6. Group 6 comprises 38 skilled technology regions from Germany, northern Italy and Austria. The economic activity of these regions is high, but at the same time they are characterised by low economic growth.

7. The last (seventh) group of traditional Southern regions includes 39 areas from Southern Europe (Portugal, Greece, Italy, Spain) with low economic growth. The economy of these regions relies mostly on agriculture and tourism.

The division proposed by the authors is wider than the traditional juxtaposition of gross domestic products or calculating innovativeness factors. It serves to outline the perspectives and directions for development of the individual regions.

\section{SMART SPECIALISATION OF REGIONS IN POLAND}

Wintjes\&Hollanders [9] classify almost all Polish regions to the group of skilled industrial Eastern EU regions (the division overlaps with the existing voivodeships). The only exception here is the Masovian Voivodeship, which has been classified as one of the public knowledge centres. The division they propose can be considered as simplified and general. There are some regions in Poland with characteristics close to those of the traditional southern regions of Europe, for example the typically agricultural region of Podkarpacie or the region of Warmia and Mazury with great tourism value. The European perspective adopted by Wintjes\&Hollenders in a way justifies the imprecise characteristic of our country. More important in the context of Poland's civilizational development is checking how individual regions realise the postulate to determine and enhancing their strong sides, which constitutes the foundation of smart specialisation of regions based on innovations.

The analysis conducted by Wintjes\&Hollanders pertains only to the economic innovativeness indicators. As for desirable directions for smart specialisation of individual regions, the authors of the diagnosis point the weaker regions toward methods of achieving the level of areas which are more economically efficient, while suggesting ways of retaining their leader position to the regions form the "top." The ensuing measures can prove to be a good surviv- 
W. BIA $Ł Y$ - The possibilities of production engineering in the development of smart specialisations illustrated with the example...

al strategy, but they will not be useful as a development strategy. This is because development assumes the use of innovations to reinforce the specific potential of the region. the choice between improving the economic status quo to the level of the wealthiest European countries and defining their own civilizational advancement path is a problem signalised more or less directly in the smart specialisation strategies of all Polish voivodeships. such an alternative proposal seems not to be the right approach as it condemns (as predicted by Wintjes\&Hollanders) poor regions to endlessly chase after the regions form the economic top, which slip away at an ever faster pace.

Focusing on the economic aspect could help facing up the challenges of the future. It is hard to predict economic conditions such as the demand for experts in particular fields or the long term profitability of companies created. However, according to its premise, smart specialisation should help regions define their current potential and find a prism through which they should organise their economic activity. Increasing innovativeness and development of a given sector should not constitute separate guidelines of the strategy - we should instead strive for innovative development of the dominating sector.

Determining the region's own socio-economic identity is the most difficult task included in the requirements for smart specialisation. regions have a tendency to mimic solutions adopted in the areas which achieved economic success. E. Sztorc [8] underlines that the process of choosing original areas of specialisation should be carefully thought through. Often, however, regions achieve the same results in priority rankings by choosing as their developmental strategy activity in the field of the most popular technologies (ICT, nano- and biotechnology). This raises the question: how many of those regions can hope to become the leader? It is easy to see, then, that a region's own potential is not enough to achieve success through smart specialisation.

\section{SMART SPECIALISATIONS OF THE SILESIAN VOIVODESHIP}

Smart Specialisations of the Silesian Voivodeship are branches/sectors of economy chosen as strategic for the development of the Silesian Voivodeship [1, 11].

The "Regional Innovation Strategy of the Silesian Voivodeship for the years 2013-2020" was approved by the Members of the Silesian Voivodeship Assembly on 20 December 2012 during the 2nd meeting of the 29th session [11]. Similarly to 2003, the Silesian Voivodeship is the first region in the country to have an innovation strategy in accordance with the Strategy of the European Union, along with the "Europe 2020" strategy. The document takes into account the newest recommendations of the European Committee pertaining to planning development for the years 2014-2020 related to the need to identify regional smart specialisations.

The main objectives of the Regional Innovation Strategy of the Silesian Voivodeship for the years 2013-2020 focus around two priorities for the innovative development of the region:

- increasing and integrating the existing potential of the region,

- creating new smart markets for future technologies.

The target for the Regional Innovation Strategy of the Silesian Voivodeship for the years 2013-2020 is to reinforce the regional innovation system and converting it toward an "innovation ecosystem."
In accordance with the idea of smart specialisations according, to which regions should especially concentrate their resources in a few key areas and develop their competitiveness based on them, three key specialisations have been identified as part of the Regional Innovation Strategy of the Silesian Voivodeship:

1. Energy production, an economic sector important to the region.

2. Medicine, which is one of the characteristics of the voivodeship within the country.

3. Information and communication technologies, which hold great importance for the technological and social development of the region.

The abovementioned decisions accepted for execution pertaining to the innovation policy of the Silesian Voivodeship when it comes to thematic smart specialisations will make it possible to strengthen the region's potential in the chosen areas, because [11]:

1. Energy production:

- is an important sector of regional and national economy,

- due to the already existing infrastructural equipment (production, transport and consumption of energy), as well as high population density and location of the industry in the region, Silesian Voivodeship is a great base for testing and full-scale implementation of innovative solutions,

- generates a suction effect not only in terms of energy production related technologies, but also when it comes to new solutions for environmental protection, information technology and automation or machine industry,

- the use of renewable energy resources in professional and industrial energy production as well as in prosumer (business and residential) groups is gaining in importance,

- in a broad understanding it constitutes the first and most important area for creating, testing and using intelligent media distribution networks, and we can transfer the experience gained from this area onto solutions for the so-called intelligent markets.

2. Medicine:

- is one of the characteristic features of the Silesian Voivodeship in the country due to its perfection in many areas of prevention, treatment and rehabilitation as well as the recognisability of medical engineering,

- is an element of public services in the context of the vision showcased in the Śląskie 2020 strategy which describes the region as one which provides access to high-standard public services,

- is connected with creating, adapting and absorbing technologically advanced solutions of medical engineering, biotechnology, materials engineering, information technology and electronics,

- is reinforced with information and communication technologies in the field of in silico research, remote prevention and diagnostics as well as treatment in complicated cases,

- developing systems of intelligent markets or quasimarkets related to serving the policyholder in the public or private systems, including international ones. 
W. BIA $Ł Y$ - The possibilities of production engineering in the development of smart specialisations illustrated with the example...

3. Information and communication technologies:

- hold a prospective significance to technological, economic and social development through increasing the accessibility to knowledge and enabling the creation and distribution of goods and services,

- make it possible to participate in global cooperation networks and the creation of transaction and management systems connected to intelligent markets,

- are connected with creating, adapting or absorbing technologically advanced solutions of materials engineering and electronics, and using design as a significant link decisive to the success of connecting the technology and product based on it with the user,

- the use of which constitutes one of the modern civilisation competences of both individuals and communities, and innovative environments.

The thematic approach used in the Regional Innovation Strategy of the Silesian Voivodeship for the years 20132020 should not be confused with the sector-oriented approach, as it opens up perspectives of development for small, medium-sized and large companies, research and development institutions, supporting organisations, and organised and individual users (prosumers) of innovations focused around the given topics, regardless of the branch of industry they belong to. A core element in these measures is the ability to switch into modes characteristic of the given thematic solutions, on both a regional and global scale.

The Regional Innovation Strategy encompassing the years 2013-2020 envisions the development and transformation of the regional system of innovation into an innovation ecosystem. The perspective of the ecosystem means [9]:

- reciprocal development of processes,

- generating solutions which have not been singled out in terms of their function, but rather naturally interfuse in thematic systems,

- co-existence, cooperation, building relations in various configurations depending on both parties' aspirations and conditions of the environment.

An ecosystem is characterised by good atmosphere and conditions for creating innovations, and the ability to selfimprove. It generates coordinated measures which strengthen the internal elements and connections, while, on the other hand, securing resources and developing connections on a larger scale, making good use of its strong sides and advantages over others.

Therefore, the vision of the region's future presented can be described as [9]:

an innovation ecosystem of the Silesian Voivodeship based

on dynamically changing innovative environments

Strengthening the regional innovation system and its conversion toward an "ecosystem" is the ambition which integrates innovative environments of the Silesian Voivodeship assigned with: agreed priorities of innovative development of the region, and joint and individual actions of all the participants of innovative processes in the Silesian Voivodeship.

\section{PRODUCTION ENGINEERING - CURRENT STATE}

The conditions of market economy and ongoing changes in the social and economic systems of the country cause transformations on the labour market - information, workers, materials, products and capital move faster and faster in ever larger quantities. Material and production costs have an increasingly smaller share in the value of products, while the costs of actions connected with acquiring and processing information pertaining to designing, manufacturing and selling the product are having an increasingly large share in the overall production. New "intangible" factors are created in the costs, connected with the emergence of new "intellectual" prime costs. At the same time, a demand emerges in companies for highly qualified staff ready to undertake new, complex tasks in quickly changing conditions, workers ready to transform their companies, elastically adjust them to the constantly appearing new challenges on the market of goods and services.

Current company managements should be a source of inspiration for forming, restructuring and reengineering production processes designed using computer technology. They should be able to motivate the employees so that they can learn about and understand the tasks they perform and have more potential chances to improve them. The company's competitiveness and profits are created in effectively working production systems.

In 1989, American Institute of Industrial Engineering (IIE) publicised a definition of the term "Production Engineering" adjusted to the production problems currently being solved, which is still in use to this day:

"Production Engineering is a term encompassing the problems of planning, designing, implementing and managing production systems, logistic systems, and securing their functioning. These systems are understood as sociotechnological systems which integrate employees, information, energy, materials, working tools and processes within the framework of the products whole life cycle. In order to achieve functioning efficiency of these systems, Production Engineering bases on technological, economic, humanistic and social sciences, utilising information and communication technology knowledge, knowledge about management, social communication and stimulating creativity among the employees. The key element which separates Production Engineering from other technical disciplines is the human factor-oriented approach. The best systems function through constantly improving the working environment, wherein human labour is the most important factor that affects efficiency, costs and the quality of work" [10].

According to this definition, Production Engineering is not a field of knowledge which should be identified only with the concepts of management, economy, marketing, techniques of production, etc. It is also not an economic or technical specialisation oriented toward solving a narrow range of problems in economic activity.

The aforementioned statements suggest that Production engineering is a science which should quickly react to the ongoing changes, "adjust" to the current challenges and help solve problems. That is why Production Engineering should take part in the development of smart specialisations.

A great challenge faced by Technical (and other) Universities of the Silesian Voivodeship is to prepare experts who would implement the Smart Specialisations accepted by the Assembly of Silesian Voivodeship. These preparations should consist in educating experts in the three specific fields (specialisations). Each of the fields deals with problems such as: management, innovation, medical and materials engineering, biotechnology, information technology, electronics, supported with information and communica- 
tion technologies. Each of these areas can be found in the "Essence of Production Engineering" brochure published by the Production Engineering Committee of the Polish Academy of Sciences (PAN), which lists the basic areas of research and management staff education within the discipline of Production Engineering [10].

In the Silesian Voivodeship, engineer's (master's) degree courses in Production Engineering are conducted as part of the Production Engineering and Management major. This major can be found at all Technical Universities located in the Silesian Voivodeship (Table 1). Both full-time and part-time first and second degree courses are conducted. With the exception of the University of Bielsko-Biała, the course is run in more than one faculty - at the Częstochowa University of Technology it is run in two faculties, and on three at the Silesian University of Technology.

Analysing the data in Table 1, we can see a very wide range of specialisations offered by the abovementioned Universities and faculties (within the same University). There are about 40 specialisations available; some of them overlap, some (judging by their names) are very similar.

This raises the following questions:

- is it justified to teach future engineers (MSc) at so many Faculties?
- is it justified to create overlapping specialisations?

- are the Faculties, then, not competing against each other?

- are the specialisations discussed with companies?

- are we prepared professionally and content-wise for so many specialisations?

- does the industry need so many high-class experts?

Moreover, this course is also offered by three Non-state (Private) Universities located in the Silesian Voivodeship (Table 2).

The situation looks similar with the Non-state Universities (Table 2) - over 40 specialisations. It raises the same questions (see above).

The Regional Innovation Strategy of the Silesian Voivodeship for the years 2013-2020 approved by the Assembly of the Silesian Voivodeship clearly specifies its goals. Analysing the three key specialisations accepted for realisation in the Silesian Voivodeship, it is easy to notice that as of this day none of the Technical Universities (both State and Non-state ones) does not offer a course with a profile that matches the strategy. Certain specialisations (as can be inferred from their names) seem to be "similar" to those accepted for realisation.

Table 1

1 State Universities in the Silesian Voivodeship which offer the Production Engineering and Management course

\begin{tabular}{|c|c|c|c|c|}
\hline No. & University & Faculty & Specialisations, 1st degree & Specialisations, 2nd degree \\
\hline 1 & $\begin{array}{l}\text { University } \\
\text { of Bielsko-Biała }\end{array}$ & $\begin{array}{l}\text { Machine } \\
\text { Construction and } \\
\text { Information } \\
\text { Technology }\end{array}$ & \multicolumn{2}{|c|}{$\begin{array}{l}\text { Production Management Engineering } \\
\text { IT Management Systems } \\
\text { Logistics systems in a company } \\
\text { Economic administration engineering }\end{array}$} \\
\hline 2 & $\begin{array}{l}\text { Częstochowa University } \\
\text { of Technology }\end{array}$ & Management & $\begin{array}{l}\text { Logistic management } \\
\text { and innovativeness } \\
\text { in the industry } \\
\text { Development management } \\
\text { and consulting } \\
\text { Information technology } \\
\text { in management } \\
\text { Health and safety management } \\
\text { Knowledge management } \\
\text { in a company } \\
\text { Production and quality man- } \\
\text { agement }\end{array}$ & $\begin{array}{l}\text { Logistic management } \\
\text { and innovativeness in the industry } \\
\text { Development management } \\
\text { and consulting } \\
\text { Production and service process improve- } \\
\text { ment } \\
\text { Information technology } \\
\text { in management } \\
\text { Health and safety management } \\
\text { Knowledge management } \\
\text { in a company }\end{array}$ \\
\hline 3 & $\begin{array}{l}\text { Częstochowa University } \\
\text { of Technology }\end{array}$ & $\begin{array}{l}\text { Production } \\
\text { Engineering } \\
\text { and Materials } \\
\text { Technology }\end{array}$ & \multicolumn{2}{|l|}{$\begin{array}{l}\text { Logistic management in a compar } \\
\text { Information technology in produc } \\
\text { and management } \\
\text { Production engineering in enviror } \\
\text { Plastically processed good produc } \\
\text { Casting production engineering }\end{array}$} \\
\hline 4 & $\begin{array}{l}\text { Silesian University } \\
\text { of Technology }\end{array}$ & $\begin{array}{l}\text { Organisation } \\
\text { and Management }\end{array}$ & $\begin{array}{l}\text { Quality, Environment } \\
\text { and Safety Management } \\
\text { in Production Engineering } \\
\text { Production System Manage- } \\
\text { ment }\end{array}$ & $\begin{array}{l}\text { Environmental Safety } \\
\text { and Protection in an Industrial Company } \\
\text { Modern Quality Management } \\
\text { in an Industrial Company } \\
\text { IT systems in Industrial Technologies } \\
\text { Production and Logistic Systems } \\
\text { in an Industrial Company }\end{array}$ \\
\hline 5 & $\begin{array}{l}\text { Silesian University } \\
\text { of Technology }\end{array}$ & $\begin{array}{l}\text { Mechanical } \\
\text { Engineering }\end{array}$ & & $\begin{array}{l}\text { Production organisation } \\
\text { Production quality and safety }\end{array}$ \\
\hline 6 & $\begin{array}{l}\text { Silesian University } \\
\text { of Technology }\end{array}$ & $\begin{array}{l}\text { Materials } \\
\text { Engineering } \\
\text { and Metallurgy }\end{array}$ & & $\begin{array}{l}\text { Occupational health and safety } \\
\text { Production engineering } \\
\text { Industrial logistics } \\
\text { Environmental protection technologies } \\
\text { Company management }\end{array}$ \\
\hline
\end{tabular}


Private Universities in the Silesian Voivodeship which run the Production Engineering and Management course

\begin{tabular}{|c|c|c|c|c|}
\hline No. & University & Faculty & Specialisations, 1st degree & Specialisations, 2nd degree \\
\hline 1 & $\begin{array}{l}\text { University } \\
\text { of Occupational Safety } \\
\text { Management } \\
\text { in Katowice }\end{array}$ & Technical Sciences & $\begin{array}{l}\text { Occupational health and safety } \\
\text { Logistics in industry and commerce } \\
\text { Processes of industrial automation } \\
\text { and robotisation } \\
\text { Welding } \\
\text { Quality management }\end{array}$ & $\begin{array}{l}\text { Chemical safety } \\
\text { Fire safety } \\
\text { Occupational health and safety } \\
\text { management in production processes } \\
\text { Environmental and waste } \\
\text { management } \\
\text { Management in logistics }\end{array}$ \\
\hline 2 & $\begin{array}{l}\text { University } \\
\text { of Dąbrowa Górnicza }\end{array}$ & $\begin{array}{l}\text { Branch Campus in } \\
\text { Cieszyn }\end{array}$ & $\begin{array}{l}\text { Public and municipal administration } \\
\text { Quality engineer } \\
\text { Human resources and payrolls } \\
\text { in practice } \\
\text { Logistics and transport } \\
\text { Marketing and sales management } \\
\text { Negotiations in business } \\
\text { Accountancy and taxes } \\
\text { in a company } \\
\text { Transport and shipping } \\
\text { Occupational health } \\
\text { and safety management } \\
\text { Management of processes } \\
\text { in administration } \\
\text { Company management } \\
\text { Human resources management } \\
\text { in a production company }\end{array}$ & $\begin{array}{l}\text { Project manager } \\
\text { Law in business } \\
\text { Accountancy and finance manage- } \\
\text { ment } \\
\text { Quality management } \\
\text { Production management } \\
\text { Company management } \\
\text { Management of a transport } \\
\text { and shipping company } \\
\text { management in administration } \\
\text { Management in logistics } \\
\text { and transport } \\
\text { Human resources management and } \\
\text { psychology in business }\end{array}$ \\
\hline 3 & $\begin{array}{l}\text { Higher School } \\
\text { of Economics } \\
\text { and Administration } \\
\text { in Bytom }\end{array}$ & $\begin{array}{l}\text { Production } \\
\text { Engineering } \\
\text { and Management }\end{array}$ & $\begin{array}{l}\text { Occupational Health and Safety } \\
\text { Management in the Production } \\
\text { Process } \\
\text { Quality and Technology Management } \\
\text { in the Production Process } \\
\text { Environmental Protection } \\
\text { Management in the Production } \\
\text { Process } \\
\text { Transport and Logistics Management } \\
\text { in the Production Process } \\
\text { and Services }\end{array}$ & $\begin{array}{l}\text { Health and safety management } \\
\text { in production companies } \\
\text { Waste management } \\
\text { Production management } \\
\text { Medical and rehabilitation equipment } \\
\text { production management } \\
\text { and industrial marketing }\end{array}$ \\
\hline
\end{tabular}

\section{CONCLUSIONS}

As underlined by the authors of the concept, smart specialisation is a strategy for all regions, not only technological leaders. Its implementation is supposed to give Europe a chance to increase its competitiveness on the global market. An argument for the concept is the necessity to concentrate funds on a specific number of priorities and goals so as not to overly divide and create overlapping measures. Also positive is the indication of the need to include monitoring and evaluation mechanisms in the strategy.

At the same time, however, the concept raises a number of fears. The quick development of science we currently observe makes it impossible for us to accurately predict which technologies, from a long-run perspective, will develop in the most dynamic way, and therefore which areas the regions should focus on to gain a competitive advantage. to a certain extent, identifying such areas is, of course, possible, e.g. as part of foresight type studies. When conducting them, special attention should be paid to the enterprise sector - what innovations are needed by the companies and what their prognoses are in terms of development of these fields. Also being indicated is the risk of concentrating development of new technologies in the most developed regions while at the same time marginalising countries and regions that are less developed, which can lead to an even bigger polarisation of regions in the European Union [7].
Part of this problem is also the education system implemented at the Pennsylvania State University (USA) [6]. The education system introduced therein is subject to a process of continuous control and improvement of the quality of teaching in order to support a multidisciplinary engineering programme adjusted to the requirements and expectations of the industry. "Educational goals" are formulated together by the management staff of the industry, graduates (exstudents) and the scientific and teaching staff, who conduct the engineering course.

Based on a continuous process of collecting and analysing data, adjustments are made at the level of the engineering course programme and the programmes for individual subjects. Changes and adjustments in individual subjects are made at the end of every semester. The need to constantly introduce changes and adjustments to the programme of the engineering course is necessary to let the students adapt to changing technologies as well as requirements and expectations of the industry.

Why shouldn't we implement these good practices at Our Universities? The author believes that there are no reasons not to; we need only good will and the motivation to improve, correct, abandon certain accepted standards or are we just going to take the easy way out?

We have a unique opportunity to introduce "smart solutions" to the Universities of the Silesian Voivodeship. 
The article is the result of the registered work with symbol 13/030/BK_16/0024 entitled

"Production engineering methods and tools for development of smart specializations" carried out in the Institute of the Production Engineering, Department of Organization and Management at Silesian University of Technology.

\section{REFERENCES}

[1] J. Brzóska. „Rozwój inteligentnych specjalizacji a wdrażanie regionalnej strategii innowacji (na przykładzie województwa śląskiego)", in Zeszyty Naukowe Politechniki Ślqskiej (s. Organizacja i Zarzqdzanie), z. 70, 2014, pp. 67-81.

[2] D. Foray. „ERA: Entrepreneurial Regional Action”, in Public Service Review: Science and Technology, no. 2, 2009.

[3] D. Foray, P.A. David and B.H. Hall. Smart specialisation. From academic idea to political instrument, the surprising career of a concept and a difficulties in its implementation [Online]. Available: https:// infoscience.epfl.ch/record/170252/files/MTEI-WP2011-001-Foray_David_Hall.pdf

[4] D. Foray and B. Van Ark. Smart specialization in a truly integrated research area is the key to attracting more $R \& D$ to Europe [Online]. Available: http:// ec.europa.eu/invest-in-research/pdf/download_en/ policy_brief1.pdf

[5] D. Foray, J. Goddard, X.G. Beldarrain et al. Guide to Research and Innovation Strategies for Smart Speciali- sation (RIS 3), Luxembourg: Publications Office of the European Union, 2012.

[6] W. Grebski and M. Grebski. „Keeping technical education aligned to the needs and expectations of industry", in Management Systems in Production Engineering, vol. 2(22), 2016, pp. 77-80.

[7] M. Kardas. „Inteligentna specjalizacja - (nowa) koncepcja polityki innowacyjnej", in Optimum. Studia Ekonomiczne, vol. 2(50), 2011, pp. 121-135.

[8] M. Świstak, E. Sztorc and J.W. Tkaczyński. Projekty europejskie. Praktyczne aspekty pozyskiwania i rozliczania dotacji unijnych, Warszawa: Wydawnictwo Beck, 2011.

[9] R. Wintjes and H. Hollanders. „Regional Innovation Report Gelderland", Report for Regional Innovation Monitor, European Commission, DG Enterprise, Brussels, 2012.

[10] Komitet Inżynierii Produkcji Polskiej Akademii Nauk. Istota Inżynierii Produkcji, Warszawa, June 2012.

[11] Sejmik Województwa Śląskiego. Regionalna Strategia Innowacji Województwa Śląskiego na lata 2013-2020, Katowice, 2012.

[12] Smart Specialisation Platform site, [Online]. Available: https://ec.europa.eu/jrc/en/science-area/innovationand-growth

dr hab. inż. Witold Biały, prof. Pol. Śl.

Silesian University of Technology, Faculty of Management and Organization Institute of Production Engineering

ul. Roosevelta 26, 41-800 Zabrze, POLAND

e-mail: wbialy@polsı.pl

Artykuł w polskiej wersji językowej dostępny na stronie internetowej czasopisma.
The article in Polish language version available on the website of the journal 